\title{
Multichannel analysis of the surface waves of earth materials in some parts of Lagos State, Nigeria
}

\author{
Večkanalna analiza površinskega valovanja v zemljinah \\ naposameznih območjih zvezne države Lagos, Nigerija
}

\author{
Adegbola, R.B. ${ }^{1,}{ }^{*}$, Oyedele, K.F. ${ }^{2}$, Adeoti, L. ${ }^{2}$, Adeloye, A.B. ${ }^{3}$ \\ ${ }^{1}$ Lagos state University, Department of Physics, Lagos, Nigeria \\ 'University of Lagos, Department of Geosciences, Akoka, Lagos, Nigeria \\ ${ }^{3}$ University of Lagos, Department of Physics, Akoka, Lagos, Nigeria \\ *adegbolaji@yahoo.com
}

\begin{abstract}
We present a method that utilizes multichannel analysis of surface waves (MASW), which was used to measure shear wave velocities, with a view to establishing the probable causes of road failure, subsidence and weakening of structures in some local government areas in Lagos, Nigeria. MASW data were acquired using a 24-channel seismograph. The acquired data were processed and transformed into a two-dimensional (2-D) structure reflective of the depth and surface wave velocity distribution within a depth of $0-15 \mathrm{~m}$ beneath the surface using SURFSEIS software. The shear wave velocity data were compared with other geophysical/ borehole data that were acquired along the same profile. The comparison and correlation illustrate the accuracy and consistency of MASW-derived shear wave velocity profiles. Rigidity modulus and $N$-value were also generated. The study showed that the low velocity/very low velocity data are reflective of organic clay/ peat materials and thus likely responsible for the failure, subsidence and weakening of structures within the study areas.
\end{abstract}

Key words: multichannel analysis of surface waves (MASW), weakening of structures, rigidity modulus, standard penetration test (SPT), $N$-value, subsidence

\section{Izvleček}

V članku je predstavljena uporaba večkanalne analize površinskih valov (MASW) s katero smo preko določitve hitrosti strižnih valov v površinskih plasteh poskušali ugotoviti razloge za poškodbe cest, posedanje in oslabitve objektov na posameznih območjih zvezne države Lagos v Nigeriji. MASW meritve smo izvajali s 24-kanalnim seizmografom, pridobljeni podatki pa so bili obdelani in analizirani s pomočjo programskega paketa SURFSEIS. Rezultat so dvodimenzionalni prerezi razporeditve hitrosti strižnih valov $\mathrm{v}$ globini od 0 do $15 \mathrm{~m}$ pod površjem. Pridobljene hitrosti strižnih valov smo primerjali s podatki drugih geofizikalnih preiskav ter vrtin pridobljenih vzdolž merjenih profilov. Primerjava in korelacija globinskih profilov hitrosti strižnih valov, pridobljenih z MASW metodo, podaja dobro ujemanje. $\mathrm{V}$ nadaljevanju smo izračunali vrednosti strižnega modulu in N SPT vrednosti. Študija je pokazala, da zelo nizke in nizke strižne hitrosti odgovarjajo območjem organskih glin in šot, ki so najverjetnejši razlog za porušitve, posedanje in oslabitve objektov na preučevanem območju.

Ključne besede: večkanalna analiza površinskih valov (MASW), hitrost strižnih valov, posedanje, porušitve objektov, strižni modul, SPT N vrednosti 


\section{Introduction}

Seismic refraction method has been increasingly used in shallow environmental and engineering site characterization works [1]. The method is based on the generation of direct compressional wave (P-wave) using a near-surface impulsive energy, which propagates through the soil medium and is refracted along stratigraphic boundaries. The impulsive energy is generated by a seismic source that is selected based upon the length of the seismic line, the resolution desired and the environmental suitability of the seismic source.

Surface waves appearing on multichannel seismic data designed to image environmental, engineering and groundwater targets have traditionally been viewed as noise [2]. A recent development incorporating concepts from spectral analysis of surface waves developed for civil engineering applications with multitrace seismic reflection methods showed great potential for detecting -and, in some cases, delineating -anomalous subsurface materials [3]. Extending the common use of surface wave analysis techniques from the estimation of 1-D shear wave velocities to detection and/or imaging required a laterally continuous approach to data acquisition and processing. Integrating the multichannel analysis of surface waves (MASW) method with geotechnical-style data acquisition permits generation of a laterally continuous 2-D cross section of the shear wave velocity field. The MASW method requires minimal processing and is relatively insensitive to cultural interference. Comparing MASW with the redundant sampling approach used in geotechnical data acquisition provides a non-invasive method of detecting horizontal and/or vertical variations in near-surface layers' material properties.

Continuous acquisition of multichannel surface wave data along linear transects has recently shown great promise in detecting shallow voids and tunnels, mapping the bedrock surface, locating remnants of underground mines and delineating fracture systems. Cross sections generated in this manner contain information about the horizontal and vertical continuity of materials as shallow as a few meters down to depths of more than $100 \mathrm{~m}$ in some settings [4]. Decreases in the shear wave velocity related to decreases in compaction or localized increases in shear wave velocity likely associated with the tension dome surrounding subsurface cavities appear to be key indicators of either active subsidence or areas susceptible to roof collapse, respectively [2]. In situations in which subsidence is active, a dramatic drop in shear wave velocity seems characteristic of areas where earth materials have begun subsiding into voids [3]. This low-velocity zone produces a unique signature in the shear wave velocity field. The key to exploiting surface waves as a site characterization tool resides in their sensitivity to shear wave velocity, compressional wave velocity, density and layering of the halfspace [5].

In this study, the seismic refraction method using the MASW technique was used as a geophysical tool with a view to generating shear wave velocity profiles in some local government areas, namely, Ojo, Alimosho, Surulere and Kosofe in Lagos State, Nigeria. Borehole data were also used as constraints in this study. These combined techniques provide confirmatory information on the subsurface structural features. The general aim of the study is to apply MASW to understanding the probable causes of collapsed and failed structures in some local government areas in Lagos State.

\section{Materials and methods}

\section{Geology of the study area}

The study area is situated in Lagos State, which is sandwiched between latitudes $7^{\circ} 14^{\prime} \mathrm{N}$ and $7^{\circ} 33^{\prime} \mathrm{N}$ and it straddles longitudes $5^{\circ} 22^{\prime} \mathrm{E}-5^{\circ} 42^{\prime} \mathrm{E}$. Lagos State is made up of coastal plain sands, clays and sandstone [6]. Geologically, Lagos lies within Dahomey Basin, which extends from Accra in Ghana through the Republic of Togo to the western flanks of Niger Delta in the east (Figure 1). According to Jones and Hockey [6], the geology of southwestern Nigeria reveals a sedimentary basin, which is classified under five major formations according to their geological formation age, namely, 


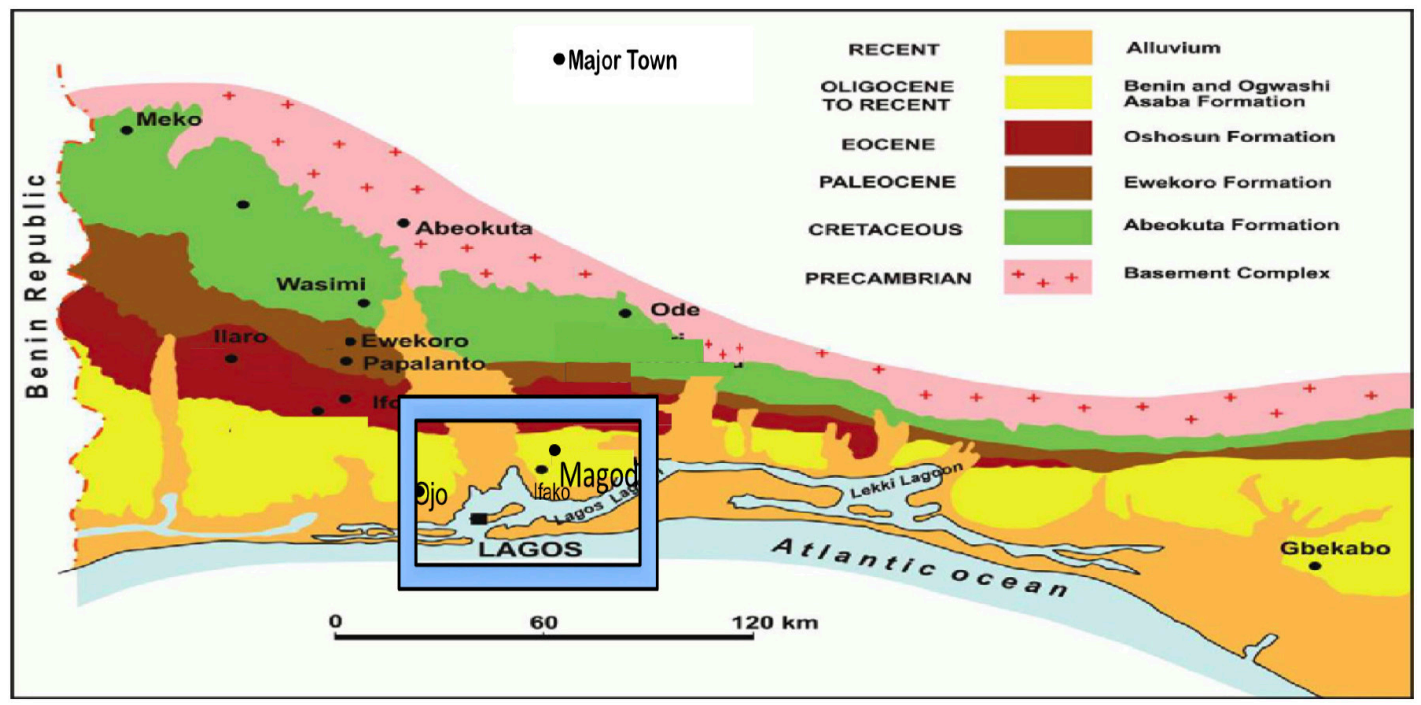

Figure 1: Geological map of Lagos State showing the study areas [9].

the Littoral and the Lagoon deposits, Coastal Plain sands, the Ilaro formation, the Ewekoro formation and the Abeokuta formation overlying the crystalline basement complex, with their ages ranging from Recent to Cretaceous. As part of the Nigerian sector of the Benin Basin, the Quaternary geology of the study area comprises the Benin Formation (Miocene to Recent), recent littoral alluvium and lagoon/ coastal plain sand deposits [6-7]. The alluvial deposits consist mainly of sands, littoral and lagoon sediments formed between two barrier beaches [8] and coastal plain sands. Topographically, the land on the northern fringe of the state has soils that do not rise very much above sea level.

\section{Data acquisition}

In this study, field measurements were conducted using the McSeis-160 portable 24-channel seismograph with seismological geophones. The roll-along technique was adopted at every $2 \mathrm{~m}$ along the entire line, and it was successfully used to record 20 shot records in the study areas. A 24-channel geophone array and three impacts of a $10 \mathrm{~kg}$ hammer vertically stacked on a $0.06 \mathrm{~m}^{2}$ plate were used for the recordings at each station. The geophone was spaced $2 \mathrm{~m}$ apart along the profile. The source to the nearest-receiver offsets was $2 \mathrm{~m}$, making the source to the farthest geophone approximately $48 \mathrm{~m}$. The source receiver configuration spacing was also for $2 \mathrm{~m}$; this recording geometry provided the optimum spread and data characteristics needed for examining the earth materials at the depths between $0 \mathrm{~m}$ and $24 \mathrm{~m}$.

\section{Data processing}

The data acquired were processed systematically, which consisted of three steps. First was the preliminary detection of surface waves (Figure 2). Second, construction of the dispersion image and extracting the signal dispersion curve were completed; and finally, the extracted dispersion curve was used as reference to back-calculate the variation of shear wave velocity (Vs) with depth. All these steps can be fully automated using the software called SURFSEIS.

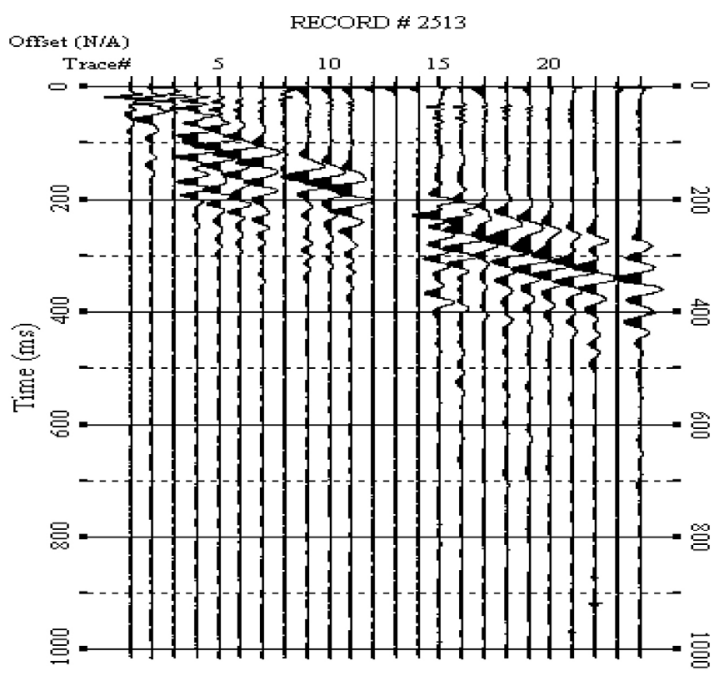

Figure 2: A typical seismogram of MASW measurement. 


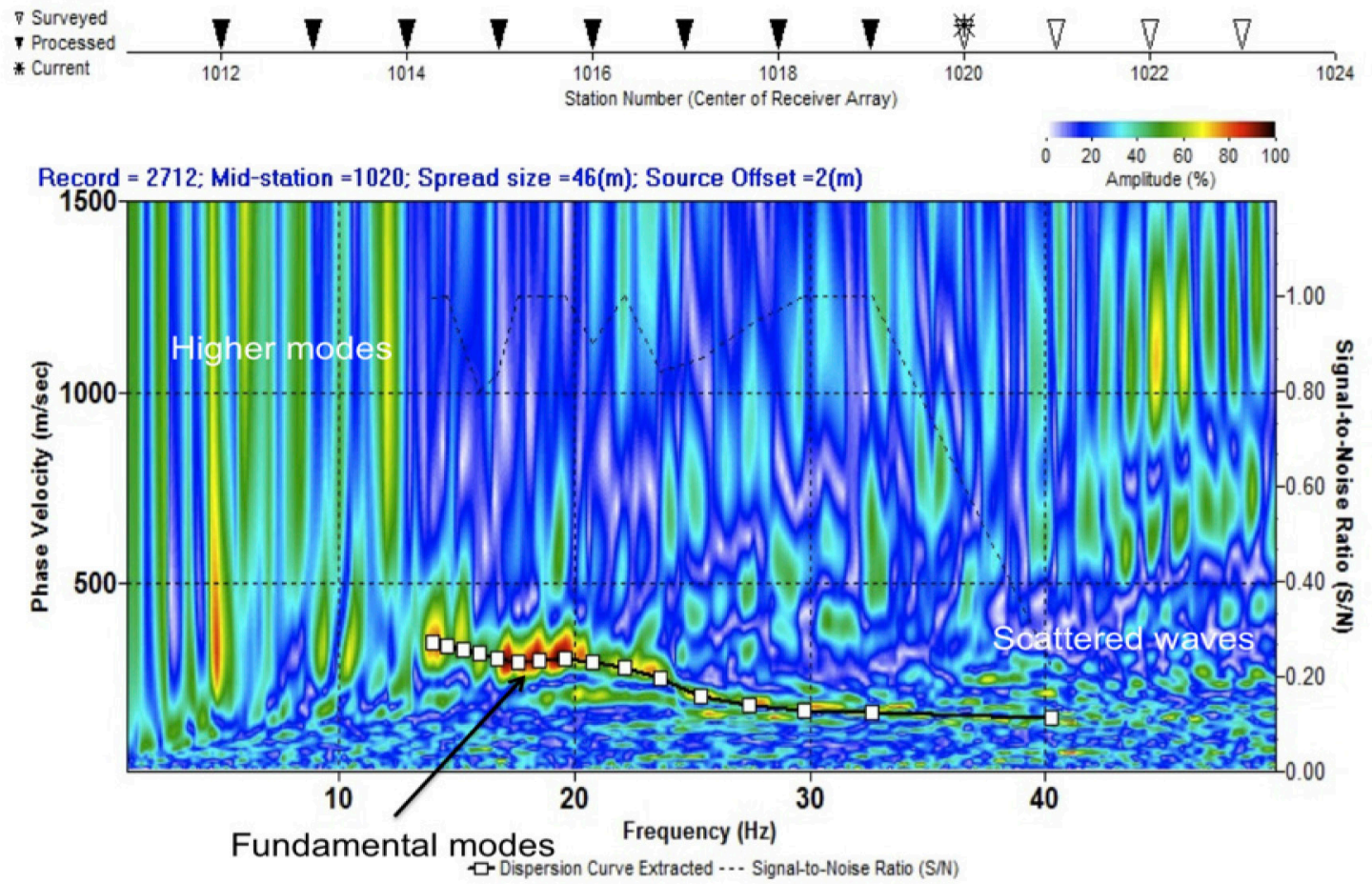

Figure 3: Dispersion image of MASW measurement.

\section{Detection of surface waves}

The signal recorded by the acquisition device, McSeis-160, was stored in the time domain and depicted as a seismogram, whereby the wave fields were identified. A good estimate of phase velocity range was made, corresponding to a particular surface wave frequency. This frequency is called the reference frequency, and the corresponding phase velocity is called apparent phase velocity.

Figure 2 is a typical seismic record showing the surface waves obtained in one of the study areas. It shows the time domain output for 24 receivers obtained through a single shot, which was recorded during data acquisition. Highly dispersive surface waves dominated most of the seismic energy, with no other seismic events identifiable. These aided in arriving at a good estimate of an approximate phase velocity range. This information was used to initiate the analysis for the phase velocity corresponding to surface wave frequency within the greatest coherency throughout the entire range of offset and the highest signal-to-noise ratio.

\section{Dispersion image}

Construction of the dispersion image panel was accomplished through a 2-D wave field transformation method that uses several pattern recognition approaches. This transformation eliminates all the ambient noise due to human activities as well as source-generated noise.

Figure 3 defines the frequency and phase velocity of each record; this displays the dispersive nature and effective delineation of surface waves. It shows the relationship between phase velocity and frequency for waves propagated horizontally directly from the impact point to the receiver line.

The dispersion image displays the trend for the fundamental mode among multiple modes possibly existing together. The extracted dispersion curves were used for the inversion to generate the $V s$ profile.

\section{Inversion}

The inversion process yielded the estimated velocity from the dispersion characteristics. A least-squares approach allows automation of the process [5]. A Monte Carlo method was adopted in this study, which generated more than 5 million models to fit the experimen- 


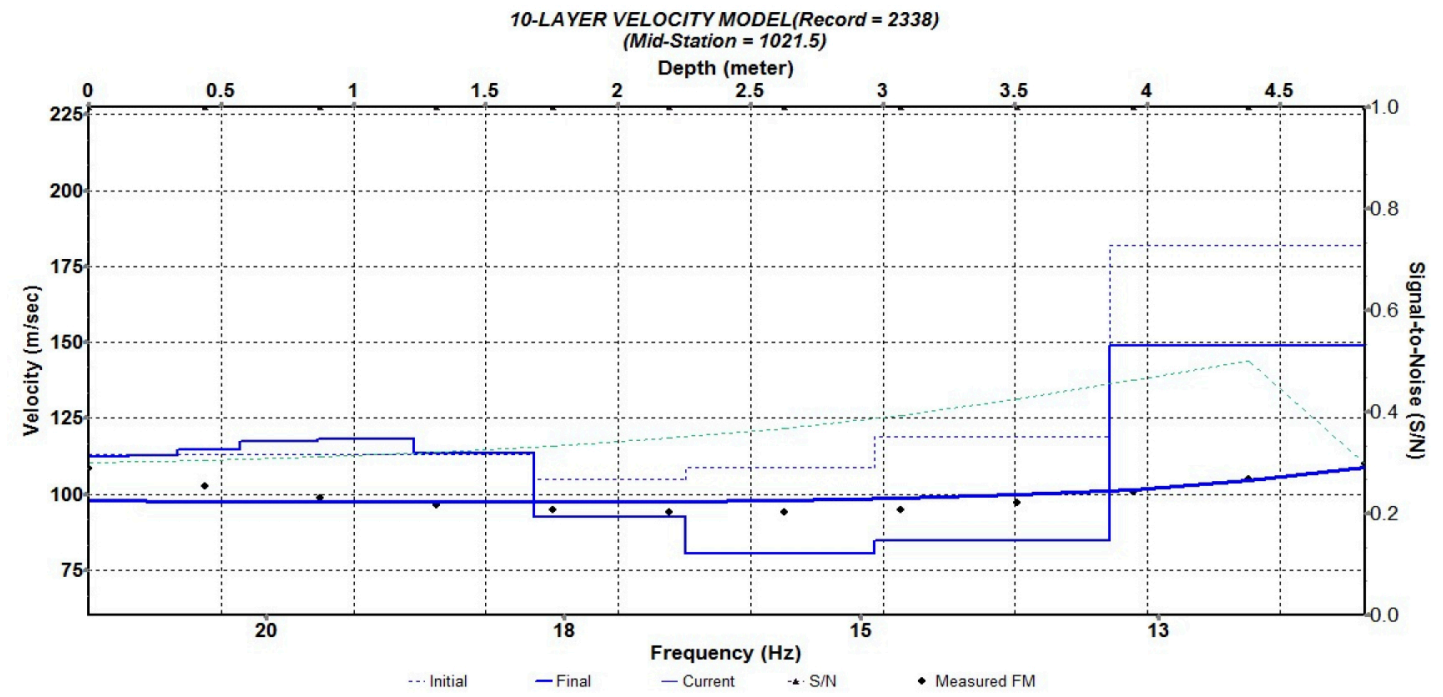

Figure 4: A typical one-dimensional (1-D) shear wave velocity profile of MASW measurement.

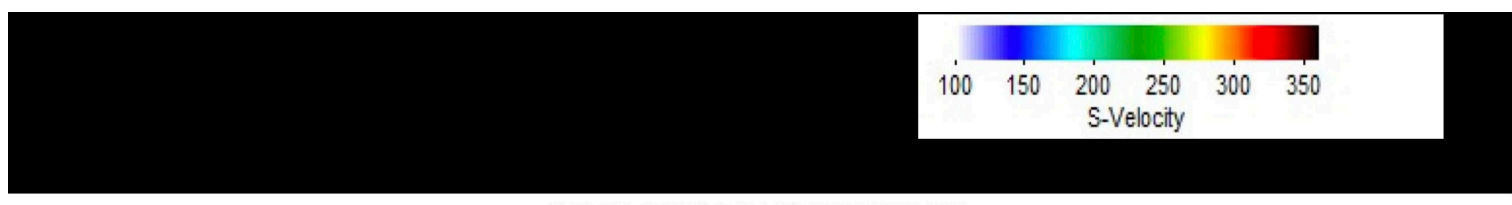

Surface Location (Station Number)

024681012141618202224262830323436384042444648505254565860626466687072

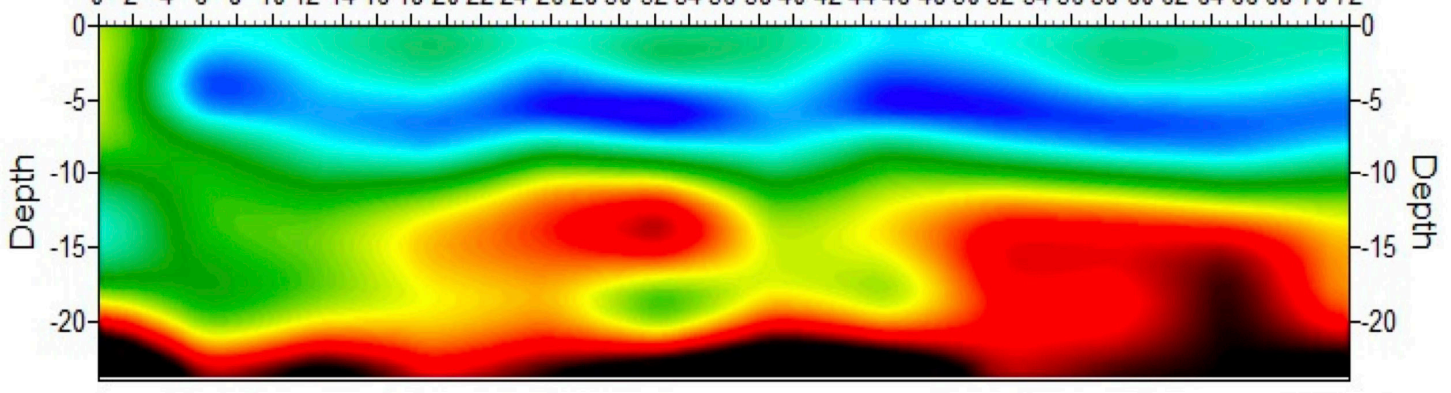

$\Delta$ Location of 1-D Vs Profile Used

2 Stations

Figure 5: A typical two-dimensional (2-D) shear wave velocity profile of MASW measurement.

tal data [10]. Either a 1-D (Figure 4) or 2-D (Figure 5) shear velocity (Vs) profile is obtained at the end of the inversion process depending on whether single or multiple dispersion curves are processed.

The study adopted the use of the Monte Carlo method of inversion because the method searches for a ten- to fifteen-layered earth model, and it is automatic and iterative, in addition to the search being a random process.

\section{Estimation of $m$ and $N$-values}

One of the most reliable methods to characterize small strain shear modulus $(\mu)$ is in situ measurement of shear wave velocity $(\mathrm{Vs})$ in the field at small strains using seismic methods [11]. The value of $m$ can be determined from the measured shear wave velocity $(\mathrm{Vs})$ profile by assuming (average: $2,000 \mathrm{~kg} / \mathrm{m}^{3}$ ) the density $r$ as follows:

$\mu=\rho V_{s}^{2}$

Correlation results of $V \mathrm{~s}$ and $N$ of Ohta and Goto [12] were adopted in the study. Hence, 


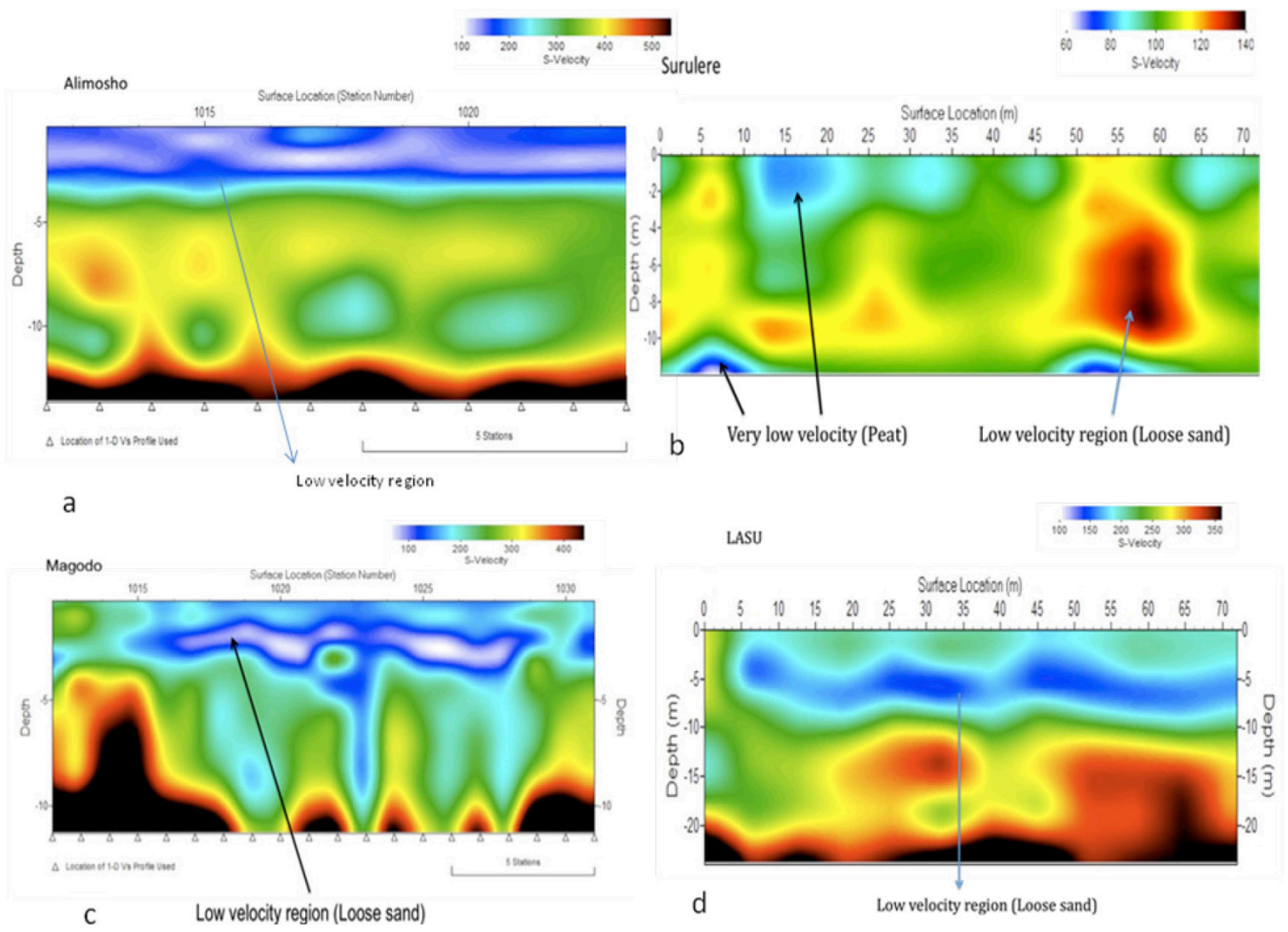

Figure 6: MASW profiles obtained from the study areas: (a) Alimosho, (b) Surulere, (c) Magodo and (d) Lagos State University.

it can also be used to estimate $\mu$ by assuming the density of soil, because slight variation of density does not influence the estimated value [13]. The predicted correlation between $N$-values and the measured shear wave velocity is given in Equation 2.0 [12]:

$V \mathrm{~S}=85.34 \cdot N^{0.348} \mathrm{~m} / \mathrm{s}$

\section{Results and discussion}

Two-dimensional cross sections of the shear wave velocity profiles (Figure 6) derived as part of the study show important characteristics that depict the nature of the subsurface within the study area. The results of the quantitative analysis are presented in Table 1, which shows the shear wave velocity and the depth of the various formations. Borehole data acquired prior to the seismic survey provided the baseline for identifying the bedrock on the shear wave profiles.
Three geological layers (clay/peat, loose/soft soil and dense/stiff soil) were found in the study area; the delineation of sediments was observed to have little variation from one location to the other. However, the categorization of sediment formation was done based on the range of velocities.

The first category is made up of soft/loose soil with shear wave velocity ranging between $100 \mathrm{~m} / \mathrm{s}$ and $200 \mathrm{~m} / \mathrm{s}$, except at Surulere, where the first layer was dominated by peat/ organic clay. The second layer was saturated with medium stiff soil formation having average shear wave velocity of $150 \mathrm{~m} / \mathrm{s}$ and average thickness of $4 \mathrm{~m}$, except at Surulere, which has shear wave velocity between $60 \mathrm{~m} / \mathrm{s}$ and $90 \mathrm{~m} / \mathrm{s}$. The last geological layer probed was made up of very stiff/dense soil formation. However, at Surulere, the layer was saturated with peat/organic clay. This implies that the peat/organic or loose soil may be connected to the sinking/collapse of structures observed in the study area. 
Table 1: Interpretation of geophysical measurements.

\begin{tabular}{|c|c|c|c|c|}
\hline Location & $\begin{array}{l}\text { Depth } \\
\text { (m) }\end{array}$ & Vs $(\mathrm{m} / \mathrm{s})$ & $\begin{array}{l}\text { Shear modulus } \\
\qquad\left(\mathrm{MN} / \mathrm{m}^{2}\right)\end{array}$ & Inferred sediments \\
\hline \multirow{4}{*}{ Alimosho } & $0-4$ & $<230$ & $<105$ & Soft/loose soil \\
\hline & $4-8$ & $380-420$ & $289-353$ & Dense stiff soil \\
\hline & $8-11$ & $230-380$ & $105-289$ & Medium stiff soil \\
\hline & $>11$ & $>420$ & $>353$ & Very dense stiff soil \\
\hline \multirow{3}{*}{ Surulere } & $0-4$ & $60-90$ & $7.2-16.2$ & Peat/organic clay \\
\hline & $4-10$ & $111-140$ & $24.6-39.2$ & Soft/loose soil \\
\hline & $>10$ & $60-90$ & $7.2-16.2$ & Peat/organic clay \\
\hline \multirow{3}{*}{ Magodo } & $0-4$ & $<200$ & $<80$ & Soft/loose soil \\
\hline & $4-8$ & $200-320$ & $80-205$ & Medium dense sand \\
\hline & $8-15$ & $320-450$ & $205-405$ & Very dense stiff soil \\
\hline \multirow{3}{*}{ Lagos State University } & $0-4$ & $100-200$ & $20-80$ & Soft/loose soil \\
\hline & $4-6$ & $200-300$ & $80-180$ & Medium dense sand \\
\hline & $6-15$ & $300-370$ & $180-274$ & Dense stiff soil \\
\hline
\end{tabular}

Table 2: Dynamic properties from MASW.

\begin{tabular}{ccccc} 
Material status & Vs $(\mathbf{m} / \mathbf{s})$ & $\mathbf{m}\left(\mathbf{M N} / \mathbf{m}^{\mathbf{2}}\right)$ & $\mathbf{N}$ value & Inferred sediments \\
\hline Very low velocity & $<100$ & $<20$ & $<1.51$ & Peat/organic clay \\
\hline Low velocity & $100-200$ & $20-80$ & $1.51-9.81$ & Soft/loose soil \\
\hline Moderately high velocity & $200-300$ & $80-180$ & $9.81-26.41$ & Medium stiff soil \\
\hline Relatively high velocity & $300-400$ & $180-320$ & $26.41-55.86$ & Dense stiff soil \\
\hline High velocity & $>400$ & $>320$ & $>55.86$ & Very dense soil
\end{tabular}

Table 3: Comparison of geophysical and geotechnical values.

\begin{tabular}{ccc} 
Depth (m) & Shear wave velocity values $\mathbf{( m / s )}$ & Borehole log information (sediments) \\
\hline $0-4$ & $<200$ & Loose-to-medium sand \\
\hline $4-9$ & $380-420$ & Clayey sand \\
\hline $9-19$ & $>420$ & Silty clay \\
\hline $19-23$ & - & Stiff clay \\
\hline
\end{tabular}

The dynamic behaviour of soil properties has been evaluated from the shear wave velocity, which is an important parameter for seismic site characterization and determination of shear modulus. Hence, a dynamic property at low strain level for site soil layers has been determined using shear wave velocity from MASW. This test was used to evaluate the shear modulus for soil characterization and established the relation of $V s, m$ and the inferred sediment with depth.

However, a categorized dynamic properties table was drawn (Table 2) which classifies shear wave velocity profile into categories based on its status and corresponding $m, N$-value and inferred sediments. Those values obtained are in good agreement with recommendations and classifications of [14-15], where the scholars established the relationship between $N$-values and relative density in descriptiveMoreover, the National Earthquake Hazard Reduction programme provides five classes of site conditions. from hard to peat/clay, based on the average shear wave velocity. Overall, the MASW method has been used to provide reliable shear wave velocity profiles within the first $15 \mathrm{~m}$ below the surface (Table 3). 


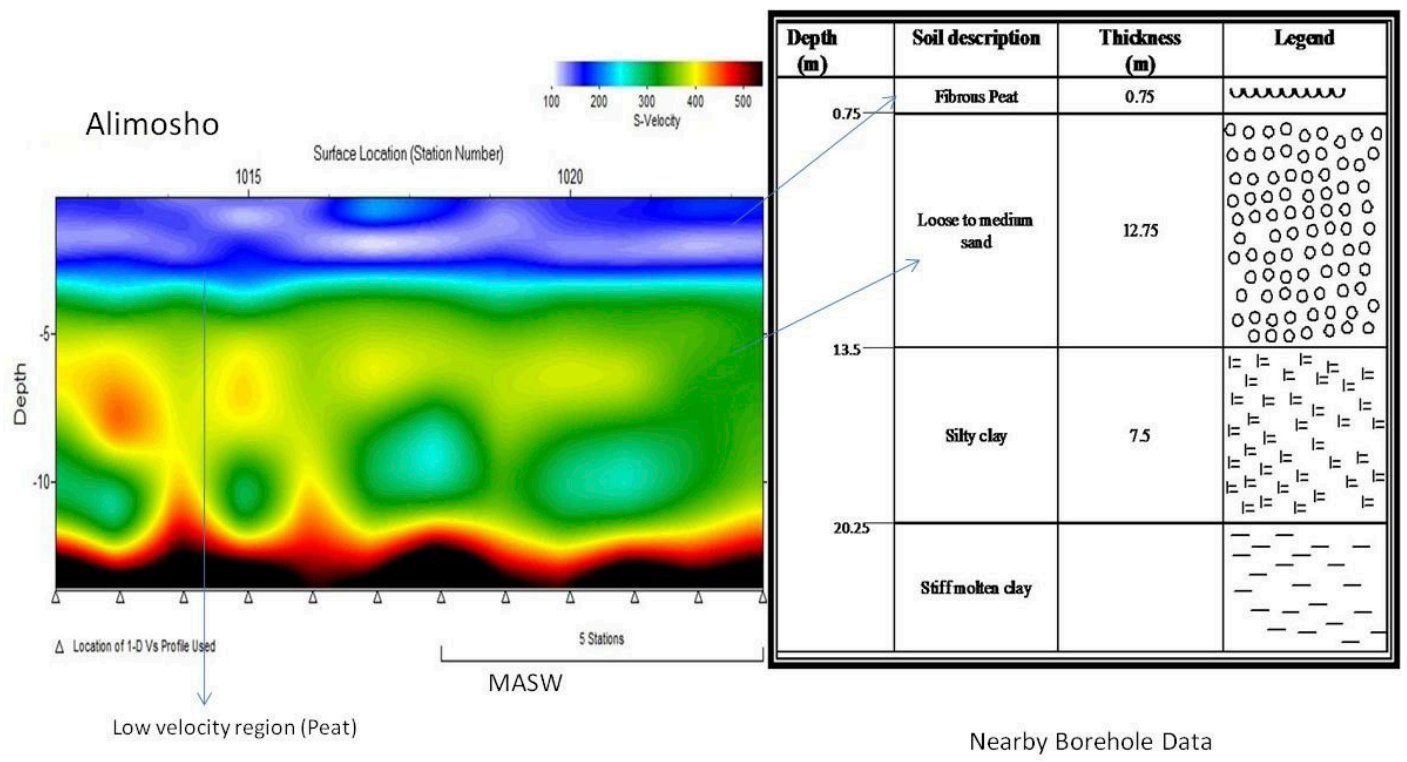

Figure 7: Typical comparison of MASW profiles and borehole data.

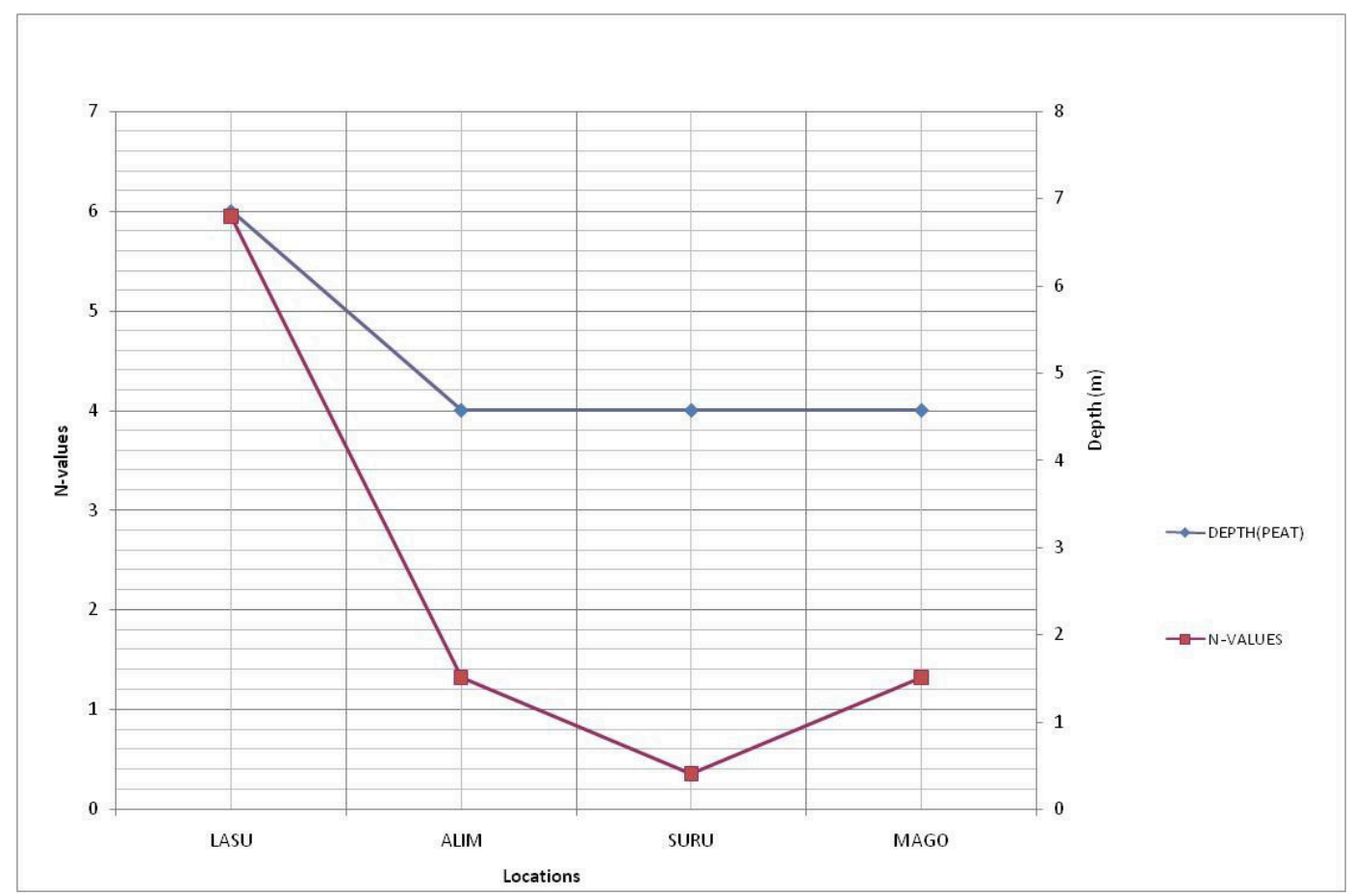

Figure 8: Depth of peat below the earth surface and $N$-value distribution against the locations.

The near-surface characterization results using the geotechnical and geophysical data were compared (Figure 7) with reported results. For instance, low shear velocity region corresponds to peat/loose soil within the same geological environment. Hence, a good correlation was inferred, although the methods provided almost the same signatures relative to depth. A plot (Figure 8) showed the depth of loose sand from the surface within the study areas. The maximum depth of the peat was observed at $6 \mathrm{~m}$ at Lagos State University in the Ojo local government area, while others were at average depth of $4 \mathrm{~m}$. In the entire study area, the $N$-val- 
ues were less than ten, which is the assumed threshold for reasonable engineering structures (Table 2). The information obtained from the plot vindicated that materials beneath the earth surface should be excavated to the depth of soft/loose soil; this will be good information for potential builders.

\section{Conclusions}

The MASW technique was used to determine the shear wave velocity in the study area with a view to characterizing the subsurface and estimating the physical properties of the earth. Shear wave velocity gradients obtained within the shear wave velocity field were consistent with drills, thus confirming the diagnostics of the subsurface structure that can be used to map velocity regions of the study area. Low shear wave velocity areas below the subsurface were classified as peat/organic clay/loose soil zones. The integrity of the MASW study was further confirmed by applying different geophysical/borehole data; the degree of correlation was very high, hence, justifying the uniqueness of the method.

\section{Acknowledgement}

The authors acknowledge the sincere contribution of Prof. Ayolabi Elijah towards the completion of this research work.

\section{References}

[1] Adegbola, R.B., Ayolabi, E. A., Allo, W. (2012): Subsurface characterization using seismic refraction and surface wave methods: a case of Lagos State University, Ojo, Lagos State. Arab J geosci. DOI 10.1007/ s12517-102-0784-2.

[2] Miller, R. D. Xia, J. Park, C.B. Ivanov, J. M. (1999): Multichannel analysis of surface waves to map bedrock. Leading Edge, 18 1392-96.

[3] Gucunski, N., Woods, R.D.(1991): Instrumentation for SASW testing, in Geotechnical, special publication no 29,Recent advances in instrumentation, data acquisition and testing in soil dynamics edited by
K.S Bhatia and G.W. Blancy, America Society of Civil Engineers. 1-16.

[4] Park, C.B., Miller ,R.D., Xia, J. (1996): Multi-channel analysis of surface waves using vibroseis, paper presented at the $66^{\text {th }}$ Ann. Mtg. of SEG, Denver, expanded abstract 68-71.

[5] Xia, J., Miller, R.D., Park, C.B. (1999): Estimation of near-surface shear-wave velocity by inversion of Rayleigh waves. Geophysics, 64 691-700.

[6] Jones, H.A., Hockey, R.D. (1964): The geology of part of South-Western Nigeria Geological Survey of Nigeria Bulletin No 31.

[7] Longe, E.O., Malomo, S., Olorunniwo, M. A. (1987): Hydrogeology of Lagos metropolis. J. Afr Earth Sci. 6(3) 163-174.

[8] Adeyemi, (1972): Sedimentology of Lagos lagoon. Unpublished B.Sc. Thesis, Obafemi Awolowo University, Ife-Ife, Osun State, Nigeria.

[9] Bankole, I.S., Schrank, E., Erdtmann, B. (2007): Palynology of the Paleogene Oshosun formation in the Dahomey basin, Southwestern Nigeria. Revista Espanola de Micropaleontologia,39 (1-2) 29-44.

[10] Socco, L.V., Strobbia, C. (2004): Surface wave method for near-surface characterization: A tutorial. NearSurface Geophysics, 165-185.

[11] Rollins, K.M., Evans, M.D., Diehl, N.B., Daily, W.D. (1998b): Shear modulus and damping relationshipsfor gravels; J. Geotech. Geoenv. Eng., ASCE 124396-405.

[12] Ohta,Y., Goto, N. (1978): Empirical shear wave velocity equations in terms of characteristics soil indexes. EarthqEngStructDyn 6(2) 167-187.

[13] Hanumantharao, C., Ramana, G.V. (2008): Dynamics soil properties for microzonation of Delhi, India J. Earth Science, 117(2) 719-730.

[14] Terzaghi, K., Peck, R.B. (1967): "Soil Mechanics in Engineering Practice" $2^{\text {nd }}$ edition, John Wiley and Sons, New York. 618p.

[15] Borcherdt, R. D.(1994):"New development in estimating site response effect on ground motion" Proc. Seminar on New development in Earthquake Ground Motion Estimation and implications for Engineering Design Practice, Applied Technology Council, ATC 35(1) 101-144. 
